\title{
PENGENDALIAN PERSEDIAAN BAHAN BAKU DENGAN PENDEKATAN TEKNIK LOT SIZING (STUDI KASUS: PT EASTERN PEARL FLOUR MAKASAR)
}

\author{
Panca Jodiawan dan Hendy Tannady \\ Program Studi Teknik Industri, Universitas Bunda Mulia \\ e-mail: hendytannady@yahoo.com
}

\begin{abstract}
ABSTRAK
Perusahaan-perusahaan Industri di Indonesia semakin meningkat seiring berjalannya waktu. Hal ini menyebabkan persaingan antar perusahaan menjadi hal yang tidak dapat dihindari. Oleh sebab itu, dibutuhkan strategi yang baik untuk menjaga keberlangsungan perusahaan dalam lingkungan seperti ini. Salah satu dari strategi yang umum digunakan adalah perencanaan dan pengendalian produksi, dimana salah satu dari komponennya adalah bahan baku. Maka, penelitian ini dilakukan untuk menganalisa dan menemukan solusi yang lebih baik terhadap periode pemesanan dan kuantitas pemesanan bahan baku sehingga dapat digunakan sebagai pertimbangan untuk mengganti kebijakan yang lama dalam perencanaan bahan baku. Data yang digunakan untuk penelitian ini diambil dari Iswara yang berjudul Analisis Pengendalian Persediaan Bahan Baku PT Eastern Pearl Flour Makassar [1]. Pendekatan yang digunakan di dalam penelitian adalah empat jenis teknik lot sizing, dua diantaranya adalah lot sizing statis, EOQ dan POQ, dan yang lainnya adalah lot sizing dinamis, heuristik SM dan PPB. Berdasarkan hasil penelitian, penghematan biaya didapatkan untuk gandum jenis AH, dari \$2.579.282,184 menjadi \$ 849.443,25 yang dihasilkan dari teknik lot sizing SM dan untuk gandum jenis APW, dari \$ 4.528.924,65 menjadi \$ 940.073,73. Oleh sebab itu, lot sizing dapat digunakan sebagai perencanaan persediaan PT Eastern Pearl Flour Makassar diwaktu yang akan datang untuk meminimalkan biaya persediaan gandum AH dan APW.
\end{abstract}

Kata kunci: Perencanaan dan Pengendalian Produksi, Lot Sizing, Bahan Baku

\begin{abstract}
Industrial's corporations in Indonesia is increasing as the time goes by. This causes the competition among corporations become an unavoidable thing. Because of this important reason, it is necessary for them to have a good strategy to keep them safe in that such environment.One of common strategy is production planning and control, which one of its component that is included in the planning is raw materials. So, this research is conducted to analyze and find the better solution in term ordering's period and its quantity which is able to be a consideration to replace the old rules for its raw material's plannning. Data in this research was taken from Iswara whose research named Analisis Pengendalian Persediaan Bahan Baku PT Eastern Pearl Flour Makassar [1]. The approach of the research used four kinds of lot sizing techniques, two among them are static lot sizing, they are EOQ and POQ, and the others are dinamic lot sizing, they are SM and PPB heuristic. Based on the research, it lead to the cost's saving for the first raw material, $A H$ wheat, from \$2.579.282, 184 to \$ 849.443,25 which technique used for it is SM heuristic and for the second raw material, APW wheat, from \$ 4.528.924,65 to \$ 940.073,73. Thus, lot sizing can be used for further inventory planning of PT Eastern Pearl Flour Makassar in order to minimize the cost of $A H$ and APW wheat's invetories.
\end{abstract}

Keywords: Production Planning and Control, Lot Sizing, Raw Material

\section{PENDAHULUAN}

Perkembangan industri di Indonesia semakin baik seiring berjalannya waktu. Di sisi lain, hal ini mengakibatkan persaingan antar perusahaan semakin meningkat. Untuk dapat bertahan, perusahaan membutuhkan strategi yang baik, sehingga jumlah jenis strategi semakin lama semakin bertambah banyak. Namun demikian, pada dasarnya setiap strategi tersebut dapat digolongkan kedalam tiga fungsional perusahaan, tiga fungsi dasar dari organisasi perusahaan tersebut adalah fungsi keuangan, fungsi operasional, dan fungsi marketing [2].

Salah satu fungsi tersebut yang memiliki potensi besar untuk terus mengalami perbaikan berkelanjutan adalah strategi operasi. Pandangan-pandangan klasik mengenai strategi operasi dikemukakan oleh Wickham Skinner yang berasal dari Harvard Bussiness School 
bahwa terdapat empat hal yang menjadi isu, salah satunya adalah rentang waktu [3]. Berdasarkan rentang waktu, keputusankeputusan operasional perusahaan dibagi menjadi tiga, yaitu pendek, menengah, dan panjang dimana sebagian besar keputusan tersebut berada pada tingkat perencanaan.

Salah satu perencanaan operasional yang krusial adalah perencanaan dan pengendalian produksi, aktivitas yang mempertimbangkan berbagai aspek, seperti ketersediaan sumber daya dan jumlah permintaan pada periode tertentu sehingga dapat menghasilkan keluaran pabrik, yaitu produk jadi, sesuai dengan kebutuhan dan biaya yang optimal [4]. Perencanaan dan pengendalian produksi dapat dilakukan terhadap berbagai jenis produk di dalam perusahaan, mulai dari bahan baku, produk setengah jadi, dan produk jadi yang kemudian diatur dalam sistem Material Requirement Planning (MRP). Hal yang paling mendasar diantara ketiga komponen yang umumnya diatur adalah bahan baku, karena tidak ada produk yang dapat dibuat bila bahan baku tidak tersedia, namun disisi lain, bila bahan baku berlebihan, maka akan mengakibatkan munculnya biaya yang tidak diperlukan.

Berbagai model pengendalian persediaan muncul sebagai respon dari permasalahan tersebut, seperti model EOQ [5], model program dinamik [6], heuristik Silver Meal [7], heuristik LUC, heuristik PPB, dan sebagainya. Dengan banyaknya model pengendalian persediaan yang tersedia, perlu dilakukan pemilihan terhadap model tersebut guna mendapatkan biaya yang optimum diantara hasil penerapan model-model pengendalian persediaan. Oleh sebab itu, analisis pengendalian persediaan bahan baku gandum jenis AH dan AWH pada PT Eastern Pearl Flour Makassar yang semula hanya dikembangkan menggunakan model EOQ [1], dianalisis kembali dengan pendekatan lot sizing dan penggunaan perhitungan biaya yang berbeda dengan penelitian sebelumnya.

Terdapat beberapa hal yang menjadi tujuan penelitian ini, yaitu: menentukan metode lot sizing yang tepat untuk setiap jenis bahan baku yang memerlukan pengendalian khusus.
Menentukan kuantitas pemesanan bila didasarkan pada metode lot sizing yang terpilih untuk setiap jenis bahan baku yang perlu pengendalian khusus. Menentukan jumlah biaya persediaan yang akan dikeluarkan bila menggunakan metode lot sizing yang terpilih. Menentukan penghematan biaya yang dapat dirasakan berdasarkan penerapan metode lot sizing yang terpilih.

\section{Persediaan}

Persediaan adalah akumulasi barangbarang tersimpan yang telah mengalami transformasi didalam proses [8]. Hampir seluruh perusahaan yang bergerak dalam industri manufaktur tentu memiliki persediaan. Persediaan di dalam industri manufaktur terdiri atas berbagai macam jenis bergantung pada jenis perusahaan dan kondisi bahannya. Jenisjenis persediaan terbagi atas: bahan baku, komponen, work in process, produk jadi dan persediaan distribusi [9].

Semakin berkembangnya dunia industri, tuntutan pelanggan juga semakin rumit dan tidak menentu. Hal ini membuat perusahaan industri manufaktur menginvestasikan sebagian dari uang perusahaan untuk menjadikannya sebagai persediaan dalam berbagai bentuk sebagaimana telah dijelaskan dalam bentukbentuk persediaan. Secara umumnya, fungsifungsi persediaan adalah sebagai berikut: memenuhi permintaan antisipasi, memperhalus kebutuhan produksi, menjaga keberlangsungan produksi dan distribusi, memberikan persiapan terhadap kehabisan stok, mengambil keuntungan dari siklus pesanan, menjadi persiapan terhadap ketidakstabilan harga bahan dan memberikan izin untuk operasi-operasi [2].

\section{Pengendalian Persediaan}

Pengendalian persediaan dapat dilakukan bila permintaan telah diketahui sumbernya. Sumber permintaan terdiri atas dua jenis, yaitu permintaan yang timbul dari pasar (independent demand) dan permintaan yang timbul akibat adanya permintaan eksternal (dependent demand). Permintaan yang timbul dari pasar biasanya berwujud produk jadi yang dikenal oleh para pelanggan, sedangkan permintaan yang timbul akibat adanya permintaan eksternal 
biasanya berwujud komponen-komponen yang digunakan untuk merakit produk jadi atau bahan baku yang dibutuhkan untuk membuat komponen-komponen produk atau pun produk jadi itu sendiri. Model pengendalian persediaan untuk independent demand adalah sebagai berikut: (1) Model Economic Order Quantity dasar, (2) Model Production Order Quantity (3) Model Quantity Discount [10].

Sedangkan untuk pengendalian persediaan untuk dependent demand adalah penggunaan Material Requirement Planning (MRP) yang didukung dengan pendekatan lot sizing. Selain sumber permintaan, hal lain yang dapat dijadikan dasar dalam mempertimbangkan model pengendalian persediaan adalah jenis permintaannya. Jenisjenis permintaan dan model pengendalian persediaan yang sesuai terdiri atas: konstan dan variabel serta diketahui dan Acak [3].

\section{Sistem Persediaan}

Persediaan memerlukan pengaturan yang baik karena terdiri atas berbagai komponen yang perlu diatur. Semakin banyaknya komponen yang perlu diatur, maka diperlukan perencanaan yang baik atas pengendalian persediaan. Oleh sebab itu, diperlukan suatu sistem dimana bagian perencana persediaan harus mampu mengatur persediaan dan mendapatkan informasi timbal balik dari hasil perencanaannya. Hal lain yang juga penting bagi perencana persediaan adalah faktor-faktor yang membuat pengendalian persediaan menjadi efektif. Pengendalian persediaan yang efektif dapat terbentuk apabila memiliki kriteria sebagai berikut: (1) Sebuah sistem untuk memantau persediaan di tangan dan di pemesanan, (1) Sebuah peramalan yang terpercaya dan memberikan indikasi mengenai kekeliruan peramalan, (2) Pengetahuan mengenai waktu tunggu dan ragamnya, (3) Perkiraan yang cukup baik mengenai biayabiaya yang terlibat dalam pengendalian persediaan, (4) Adanya sistem klasifikasi terhadap persediaan [2].

Sistem persediaan tentu akan berfungsi setiap waktunya karena hal tersebut sudah menjadi bagian aktivitas dalam perusahaan. Namun demikian, perusahaan tentu akan melakukan penilaian performa setiap aktivitas yang ada di dalamnya, termasuk sistem persediaan tersebut. Oleh sebab itu, setelah menerapkan sistem persediaan di dalam perusahaan, maka hal selanjutnya yang menjadi permasalahan adalah pengukuran performa sistem persediaan itu sendiri. Terdapat dua cara umum yang digunakan untuk mengukur performa persediaan, yaitu [11]:

\section{Inventory turnover}

Inventory turnover berhubungan dengan tingkat persediaan terhadap volume penjualan produk. Perhitungan inventory turnover adalah dengan membagi volume penjualan per tahun dengan investasi rata-rata untuk persediaan.

\section{Fill rate}

Untuk dapat mengetahui keuntungan dari adanya persediaan, maka dapat dilakukan pengukuran terhadap tingkat pelayanan pelanggan (customer service). Umumnya, tingkat pelayanan pelanggan didefinisikan dalam bentuk persentase.

\section{Biaya Persediaan}

Setiap strategi yang diterapkan perusahaan memiliki tujuan umum, yaitu peningkatan keuntungan atau penurunan biaya, termasuk strategi pengendalian sistem persediaan. Sistem persediaan yang baik tentu akan mengimplikasikan pada biaya pengadaan persediaan yang logis. Biaya persediaan merupakan salah satu kriteria yang digunakan untuk mengetahui sistem persediaan yang optimal [3]. Hal ini dapat dilakukan dengan menggunakan fungsi tujuan meminimalkan biaya persediaan. Umumnya biaya persediaan terbagi menjadi tiga kategori, yaitu :

\section{Biaya penyimpanan}

Jumlah seluruh biaya yang bersifat proporsional terhadap jumlah inventori fisik yang berada di tempat penyimpanan pada periode waktu tertentu. Beberapa contoh biaya penyimpanan adalah biaya menyediakan tempat untuk menyimpan produk, pajak dan asuransi, biaya kerusakan dan keusangan, biaya kesempatan yang muncul jikalau investasi dialihkan pada hal yang lain. Bila biaya 
penyimpanan didefinisikan dalam bentuk persentase, maka dapat dihitung dengan cara mengalikan persentase biaya penyimpanan dengan biaya investasi persediaan per unit per tahun.

\section{Biaya pemesanan}

Biaya yang bergantung pada jumlah pemesanan persediaan yang dilakukan. Dalam aplikasinya, biaya persediaan dibagi menjadi dua komponen, yaitu biaya tetap dan biaya variabel. Biaya tetap adalah biaya yang tidak terpengaruh pada jumlah unit yang dipesan, sedangkan biaya variabel adalah biaya yang sifatnya proporsional terhadap jumlah unit yang dipesan.

\section{Biaya finalti}

Biaya ini disebut juga sebagai biaya stock out, yaitu biaya yang terjadi karena tidak memiliki persediaan yang cukup untuk memenuhi seluruh permintaan pada waktu tertentu. Biaya ini dapat diartikan menjadi dua hal, yaitu biaya yang harus ditanggung karena pelanggan mendapatkan pesanannya pada waktu yang telat dan biaya yang disebut loss of goodwill, biaya yang ditanggung akibat kehilangan pelanggan. Satuan yang umumnya digunakan untuk mendefinisikan biaya finalti adalah per unit per unit waktu.

\section{Model Persediaan Dependent Demand}

Seiring dengan perkembangan zaman, sistem persediaan dikembangkan menjadi model-model tertentu, yang terbagi menjadi model pengendalian persediaan independent demand dan dependent demand. Model yang umumnya digunakan untuk mengendalikan persediaan berdasarkan dependent demand adalah MRP. Model MRP tentu membutuhkan hal-hal penunjang sebelum dapat diterapkan didalam perusahaan. Sebelum dapat membentuk MRP, ada hal-hal yang perlu diketahui, antara lain: Master Production Schedule (MPS), Bill of Material (BOM), ketersediaan penyimpanan, pesanan yang sedang diproses, dan waktu tunggu [10].

Dalam penerapannya, MRP dibentuk dalam sebuah tabel berbasis waktu (pada umumnya dalam satuan minggu), seperti pada Tabel 1.

Setiap jenis model pengendalian persediaan memiliki komponen-komponen tertentu yang diatur di dalamnya. Komponenkomponen tersebut mencerminkan kondisi persediaan yang didasarkan pada periode waktu. Komponen-komponen yang terdapat di dalam struktur tabel MRP adalah sebagai berikut: Gross Requirement, Scheduled Receipts, Projected Available dan Planned Orders [9].

\section{Lot Sizing}

Dalam penentuan planned orders, maka pendekatan lot sizing, penentuan jumlah pemesanan sekali pesan, dapat diterapkan. Lot sizing terdiri atas dua jenis, yaitu uncapacitated techniques, teknik yang hanya menggunakan biaya penyimpanan dan biaya pemesanan tanpa mempertimbangkan batasan sumber daya yang ada dan capacitated techniques, teknik yang mempertimbangkan sumber daya yang tersedia selain biaya penyimpanan dan pemesanan (produksi dalam unit yang terbatas) [12,13].

Uncapacitated techniques untuk single item terdiri atas beberapa metode, diantaranya adalah sebagai berikut: Algoritma Wagner \& Whitin, Periodic Order Quantity, Lot for Lot, Silver Meal dan Least Unit Cost. Sedangkan capacitated techniques untuk single item juga terdiri atas beberapa metode, diantaranya adalah pemakaian model matematika berbasis integer

Tabel 1. Contoh Tabel MRP [9]

Item: CD Cabinet Lead time: 1 Week

Lot size rule: 14L Beginning inventory: 0

\begin{tabular}{|c|c|c|c|c|c|c|c|c|c|c|c|c|}
\hline & 1 & 2 & 3 & 4 & 5 & 6 & 7 & 8 & 9 & 10 & 11 & 12 \\
\hline $\begin{array}{l}\text { Gross Requirement } \\
\text { Schedule Receipts }\end{array}$ & 0 & 0 & 0 & 100 & 0 & 0 & 100 & 0 & 0 & 100 & 0 & 0 \\
\hline $\begin{array}{l}\text { Projected Available } \\
\text { Planned Orders }\end{array}$ & 0 & 0 & $\begin{array}{c}0 \\
100\end{array}$ & 0 & 0 & $\begin{array}{c}0 \\
100\end{array}$ & 0 & 0 & $\begin{array}{c}0 \\
100\end{array}$ & 0 & 0 & 0 \\
\hline
\end{tabular}


programming atau pun linear programming dan pendekatan heuristik [14].

\section{Model EOQ}

Untuk mengaplikasikan formula EOQ dalam pendekatan lot sizing, dibutuhkan tiga masukan, yaitu rata-rata permintaan, biaya pernyimpanan dan biaya set up [3]. Model EOQ disebut juga sebagai model lot sizing statis karena jumlah pemesanan yang akan dipakai di dalam MRP akan terus memiliki nominal yang sama berdasarkan perhitungan telah ditetapkan dengan rumus EOQ [15,16]. Berikut adalah rumus EOQ dalam menentukan jumlah pemesanan optimal.

$$
Q=\sqrt{\frac{2 K D}{h}}
$$

\section{Dimana :}

$\mathrm{D}$ : permintaan rata-rata dalam satu tahun

$\mathrm{K}$ : biaya pemesanan

$\mathrm{h}$ : biaya penyimpanan per unit per tahun

$\mathrm{Q}$ : jumlah pemesanan

Model EOQ dasar dapat diterapkan bila asumsi-asumsi berikut dapat terpenuhi: (1) Permintaan per satuan waktu diketahui, konstan dan independen, (2) Waktu tunggu diketahui dan konstan (Hal ini berarti tidak diizinkan terdapat ragam pada waktu tunggu), (3) Penerimaan jumlah pemesanan hanya sekali untuk satu kali pemesana, (4) Tidak diizinkan adanya pemotongan harga bila ada pemesanan kuantitas tertentu [10].

\section{Period Order Quantity (POQ)}

Metode ini menggunakan model EOQ dasar dengan cara menghitung sebuah waktu yang tetap untuk melakukan pemesanan. Oleh sebab itu, POQ menghindari sisa persediaan karena pemesanan dilakukan berdasarkan jumlah kebutuhan dalam rentang waktu tertentu. Dalam kondisi permintaan per satuan waktu yang terendah, biaya pemesanan yang relatif tinggi dan jumlah struktur pada BOM relatif sedikit, maka pendekatan POQ akan menghasilkan biaya yang lebih rendah dibandingkan dengan pendekatan Lot for Lot [17].

\section{Silver Meal Heuristic (SM)}

Pendekatan ini merupakan sebuah metode penghitungan maju (forward method) yang menentukan biaya rata-rata per periode sebagai sebuah fungsi dari jumlah periode dari satu waktu kewaktu lain, dan kriteria penghentian dilakukan bila menemukan kenaikan biaya ratarata pada waktu tertentu. Berikut adalah rumus dari pendekatan SM [3].

$$
C(j)=\left(K+h r_{2}+2 h r_{3}+\ldots+(j-1) h r_{j}\right) / j
$$

\section{Dimana:}

$$
\begin{aligned}
& \mathrm{K} \quad \text { : biaya set up/pemesanan } \\
& \mathrm{r}_{\mathrm{j}} \quad \text { : tingkat permintaan periode } \mathrm{j} \\
& \mathrm{j} \quad \text { : periode waktu } \\
& \mathrm{h} \quad \text { : biaya penyimpanan } \\
& \mathrm{C}(\mathrm{j}) \text { : biaya rata-rata per periode }
\end{aligned}
$$

Ketika $\quad \mathrm{C}(\mathrm{j})>\mathrm{C}(\mathrm{j}-1), \quad$ perhitungan dihentikan dan jumlah pemesanan adalah total permintaan dari permintaan periode ke satu sampai periode j-1. Setelah ditentukan jumlah pemesanan tersebut, maka proses dilanjutkan dan dimulai dari periode $\mathrm{j}$.

\section{Part Period Balancing (PPB)}

Walaupun pendekatan SM terlihat memberikan hasil yang lebih baik dalam berbagai permasalahan yang pernah terjadi, tetapi pendekatan PPB terlihat lebih populer dalam praktiknya. Metode ini mengurutkan rentang pemesanan dan mencari rentang periode tertentu dengan tujuan penyetaraan total biaya set up dan total biaya penyimpanan yang terlibat sedapat mungkin [3].

\section{Kriteria Penilaian Lot Sizing}

Berdasarkan keadaan nyata dalam pengendalian persediaan, bukan hanya aspek biaya yang dipertimbangkan oleh perusahaan dalam pengambilan keputusan. Terdapat faktorfaktor lain yang perlu dipertimbangkan dalam menentukan besarnya ukuran lot karena situasi nyata industri lebih kompleks daripada yang diasumsikan dalam teori-teori pengendalian persediaan. Terdapat hal-hal lain diluar aspek 
biaya yang menjadi penilaian kinerja dari pendekatan lot sizing [18]. Hal-hal tersebut adalah sebagai berikut:

\section{Variabilitas ukuran lot}

Setiap pendekatan pada lot sizing dinamis pada umumnya akan melakukan pemesanan secara fluktuatif, sehingga jumlah pemesanan untuk sekali pesan tidak sama dari satu periode ke periode yang lain. Hal ini perlu menjadi pertimbangan karena dalam dunia industri, para manajer pembelian atau pun manajer produksi menganggap ini adalah hal yang penting [18].

\section{Kestabilan sistem}

Stabilitas sistem melibatkan stabilitas waktu penjadwalan produksi dan pengiriman produk. Hal ini menjadi penting karena dalam dunia industri, permintaan tidak dapat diketahui secara pasti. Oleh sebab itu, pengiriman dapat dimundurkan atau dimajukan sesuai dengan pembaharuan permintaan di dalam sistem MRP. Salah satu cara untuk mengatasi ketidakpastian dalam permintaan adalah menerapkan frozen period pada rentang waktu tertentu [18]. Hal ini memberikan jumlah permintaan yang pasti pada periode waktu tertentu sehingga mengurangi pemajuan atau pemunduran dari waktu produksi atau waktu pengiriman.

\section{Tingkat layanan ( Service level )}

Tingkat layanan didefinisikan sebagai persentase dari permintaan konsumen yang dipenuhi tepat waktu tanpa adanya penundaan sebagian ataupun seluruhnya [18]. Pada penelitiannya, diterangkan bahwa terdapat hubungan antara kesalahan yang terjadi pada peramalan permintaan terhadap tingkat layanan.

\section{Pengendalian Multi Produk}

Pada beberapa perusahaan, persediaan produk tidak hanya terbatas pada satu jenis, tetapi dapat berjumlah cukup banyak. Hal ini tentu akan mempersulit perusahaan bila pengendalian persediaan pada tingkat yang sama diterapkan pada seluruh jenis produk tersebut. Oleh karena itu, perlu klasifikasi persediaan sehingga perusahaan dapat menentukan pengendalian persediaan yang sesuai untuk klasifikasi tersebut.
Hukum Pareto dapat diterapkan untuk menentukan tingkat pengendalian persediaan yang dibutuhkan terhadap produk tertentu [9]. Hukum Pareto memberitahu bahwa secara kasar, sepuluh sampai dua puluh persen jenis persediaan di tempat penyimpanan, ternyata merupakan enam puluh sampai delapan puluh persen dari total biaya persediaan. Oleh sebab itu, persediaan yang sangat mempengaruhi biaya persediaan tentu akan memiliki tingkat pengendalian yang lebih tinggi sehingga dapat menekan biaya persediaan lebih signifikan dibandingkan dengan yang lain. Persediaan yang hanya merepresentasikan sekitar lima belas persen dari seluruh jenis produk, tetapi merepresentasikan sekitar tujuh puluh sampai delapan puluh persen dari seluruh total biaya persediaan digolongkan ke dalam kelas A [10]. Persediaan yang merepresentasikan sekitar tiga puluh persen dari seluruh jenis produk dan sekitar lima belas sampai dua puluh lima persen dari total biaya persediaan digolongkan kedalam kelas B. Persediaan yang hanya merepresentasikan sekitar lima persen dari seluruh biaya persediaan dengan jenis produk sekitar lima puluh lima persen dari seluruh total persediaan produk dikelompokkan menjadi kelas C.

\section{METODE PENELITIAN \\ Diagram Alir Penelitian Ruang Lingkup Penelitian}

Ruang lingkup penelitian ini adalah sebagai berikut: mengidentifikasi dan formulasi permasalahan dilakukan berdasarkan data sekunder yang diambil dari data skripsi Universitas Hassanudin dengan judul Analisis Pengendalian Persediaan Bahan Baku pada PT Eastern Pearl Flour Makassar karya Alfiana Adila Iswara. Periode permintaan adalah satu tahun, dari Januari 2013 sampai Desember 2013. Penerapan model terbatas pada dua jenis bahan baku, yaitu Australian Hard (AH) dan Australian Premium White (APH). Teknik lot sizing didasarkan pada kebijakan tanpa safety stock. Teknik lot sizing yang digunakan adalah Economic Order Quantity (EOQ), Period Order Quantity (POQ), Silver and Meal (SM), dan Part Period Balancing (PPB). Pengendalian bahan baku adalah yang tergolong jenis $\mathrm{A}$. 
Teknik lot sizing yang digunakan diasumsikan tidak memiliki batasan kapasitas.

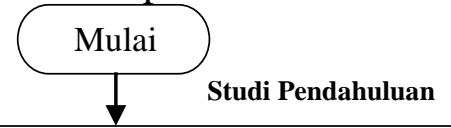

Identifikasi Masalah

Berdasarkan identifikasi masalah yang dilakukan didapatkan bahwa permintaan yang terdapat pada PT. Eastern Pearl Flour Makasar tahun 2013 tidak sama rata untuk setiap bulan. Sehingga model EOQ di dalam skripsi perlu mengalami perbaikan

Perumusan Masalah

Metode lot sizing apa yang tepat untuk pengendalian bahan baku AH dan AWH? Berapa kwantitas pemesanan dan biaya yang dikeluarkan bila menggunakan metode lot sizing yang terpilih? Berapa penghematan biaya yang dapat dirasakan bila menggunakan metode lot sizing

Pengumpulan dan Pengolahan Data

Pengumpulan Data

- Data penggunaan AH dan AWH tahun 2013

- Data penerimaan AH dan AWH sekali pesan

- Data stok awal penerimaan dan stok akhir AH dan AWH tahun 2013

- Waktu tunggu pemesanan

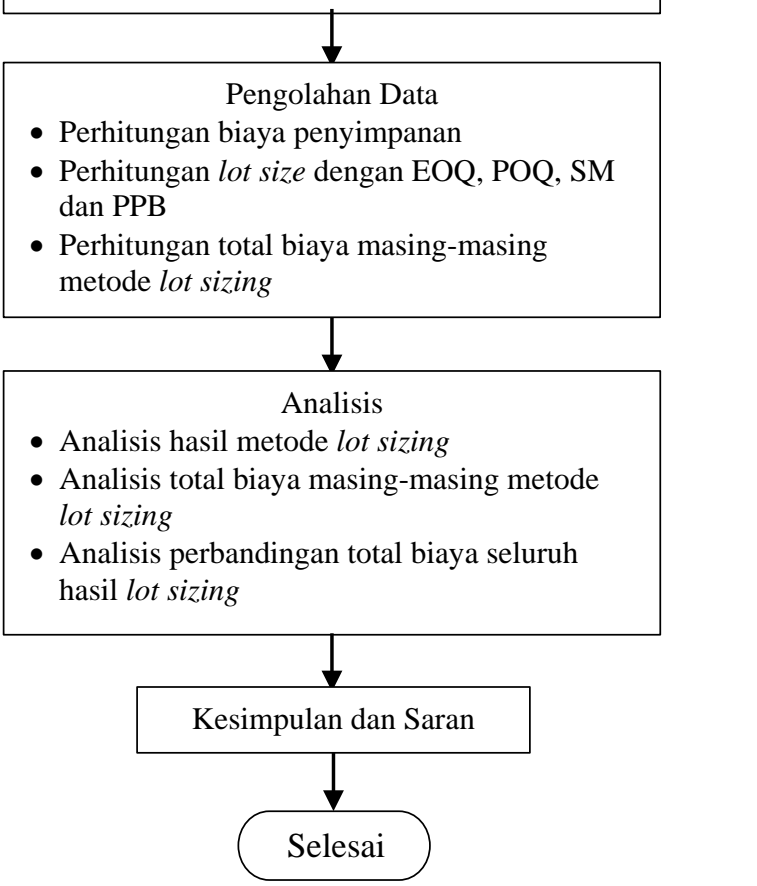

Gambar 1. Diagram Alir Penelitian

\section{Pengumpulan dan Pengolahan Data}

Pengambilan data pada penelitian ini dilakukan dengan mencari data sekunder, yaitu data yang berasal dari data skripsi Universitas Hassanudin dengan judul Analisis Pengendalian Persediaan Bahan Baku pada PT Eastern Pearl Flour Makassar karya Alfiana
Adila Iswara. Terdapat data yang dibutuhkan, tetapi tidak ada di dalam skripsi tersebut, yaitu data pemakaian bahan baku per minggu. Oleh sebab itu, penentuan pemakaian bahan baku per minggu diasumsikan terbagi rata dari data pemakaian bahan baku per bulan sesuai dengan pertanggalan aktif tahun 2013.

Pengolahan data pada penelitian ini adalah sebagai berikut: (1) Data kuantitatif yang terdapat di dalam skripsi disusun kembali dan disesuaikan urutannya oleh peneliti, (2) Perhitungan biaya penyimpanan yang baru dengan menggunakan biaya kesempatan yang hilang akibat adanya investasi, (3) Penggunaan setiap model lot sizing yang telah disebutkan pada ruang lingkup penelitian, yaitu EOQ, POQ, SM, dan PPB, (4) Menggunakan tabel untuk menyajikan hasil perhitungan setiap metode lot sizing, (5) Menyusun tabel MRP menggunakan bantuan software Microsoft Excel 2007 berdasarkan perhitungan setiap model lot sizing dengan kebijakan tanpa safety stock.

\section{HASIL DAN PEMBAHASAN Analisis Biaya Persediaan}

Berdasarkan tinjauan pustaka, biaya persediaan terdiri atas dua jenis, yaitu biaya penyimpanan dan biaya pemesanan. Pada penelitian ini, biaya penyimpanan yang digunakan didasarkan atas biaya opportunity atau biaya kesempatan yang merupakan jumlah uang yang mungkin didapatkan bila investasi persediaan gandum dialihkan kepada proyek lain. Biaya opportunity dikaji dalam satuan dollar per unit per tahun dan didapatkan dari hasil kali antara MARR dan biaya pembelian gandum per unit. Pendekatan yang digunakan untuk nilai MARR adalah rata-rata tingkat bunga berdasarkan data Bank Indonesia tahun 2013, yaitu 6,42 \%. Berikut adalah biaya penyimpanan kedua jenis gandum.

Biaya pemesanan yang digunakan adalah biaya pemesanan yang berbeda jenis dengan yang digunakan di dalam Iswara (2014). Biaya pemesanan yang digunakan di dalam Iswara (2014) sebenarnya tidak dapat digunakan untuk model lot sizing karena jenis biaya pemesanan yang digunakan bersifat variabel, sehingga dipengaruhi oleh banyak sedikitnya kuantitas 
Tabel 1. Biaya Penyimpanan

\begin{tabular}{cccc}
\hline Jenis Gandum & MARR & Biaya Pembelian (\$) & Biaya Persediaan per tahun (\$) \\
\hline Gandum AH & \multirow{2}{*}{$6,42 \%$} & 340 & 21,828 \\
Gandum APW & 350 & 22,470 \\
\hline
\end{tabular}

pemesanan sekali pesan. Oleh sebab itu, di dalam penelitian ini, biaya pemesanan yang dipilih adalah yang bersifat tetap, sehingga tidak dipengaruhi oleh banyak sedikitnya kuantitas pemesanan sekali pesan. Pendekatan yang dilakukan adalah dengan menggunakan biaya yang diestimasi dan asumsi persentase pajak yang dikenakan hanya dihitung berdasarkan biaya pemesanan yang bersifat tetap dan tidak memasukkan perhitungan pajak terhadap kuantitas pemesanan. Berikut adalah biaya pemesanan sekali pesan.

Tabel 2. Biaya Pemesanan

\begin{tabular}{ccc}
\hline Jenis Gandum & Komponen & Total Biaya \\
\hline Gandum AH & $\begin{array}{c}\text { Biaya Pengiriman } \\
\text { Pajak impor }\end{array}$ & 2562,15 \\
\hline Gandum APW & $\begin{array}{c}\text { Biaya Pengiriman } \\
\text { Pajak impor }\end{array}$ & 2562,15 \\
\hline
\end{tabular}

\section{Analisis Usulan Persediaan Model EOQ}

Model EOQ adalah salah satu teknik lot sizing yang bersifat statis. Hal ini berarti terdapat suatu komponen yang memiliki nilai yang tetap pada hasil EOQ. Nilai tersebut adalah kuantitas pemesanan. Di dalam penelitian ini, kuantitas pemesanan menggunakan satuan metric ton dan perhitungan biaya didasarkan pada penyimpanan akhir setiap bulan.

Berdasarkan Tabel 3, ada tiga komponen yang tertulis, yaitu unit pemesanan, jumlah pemesanan, dan total investasi persediaan. Komponen pertama, unit pemesanan, merupakan kuantitas pemesanan sekali pesan, bernilai 4955,2 mt untuk gandum AH dan 7538 mt untuk gandum APW. Komponen kedua, jumlah pemesanan, merupakan frekuensi pemesanan yang akan dilakukan bila menggunakan model EOQ, bernilai 15 kali untuk gandum $\mathrm{AH}$ dan 33 kali untuk gandum APW. Komponen terakhir, total investasi persediaan, merupakan jumlah investasi persediaan yang disusun berdasarkan persediaan akhir setiap bulannya untuk satu tahun pada saat pembelian terjadi, bernilai 38.754,2 mt untuk gandum $\mathrm{AH}$ dan $38.074 \mathrm{mt}$ untuk gandum APW.

Kuantitas pemesanan untuk gandum APW memiliki nilai yang lebih besar daripada gandum AH. Hal ini terjadi karena jumlah pemakaian kedua jenis gandum yang berbeda. Berdasarkan rumus yang tersedia di dalam landasan teori, maka terlihat apabila nilai permintaan per tahun semakin besar, kuantitas pemesanan akan semakin besar juga. Permintaan per tahun untuk gandum AH adalah $104.650 \mathrm{mt}$ dan untuk gandum APW adalah $249.050 \mathrm{mt}$. Berdasarkan alasan tersebut, kuantitas pemesanan gandum APW lebih besar dibandingkan dengan gandum $\mathrm{AH}$.

Hal yang sama terjadi pada frekuensi pemesanan. Terlihat bahwa frekuensi pemesanan pada gandum AH lebih sedikit dibandingkan dengan gandum APW. Ada dua hal yang mempengaruhi frekuensi pemesanan kedua jenis gandum, yaitu kuantitas pemesanan dan jumlah permintaan satu tahun. Dengan nilai jumlah permintaan satu tahun yang sama, tetapi kuantitas pemesanan yang berbeda akan menghasilkan frekuensi pemesanan yang berbeda. Kuantitas pemesanan yang lebih kecil akan menghasilkan frekuensi pemesanan yang lebih tinggi dan sebaliknya. Hal yang sama akan terjadi bila kuantitas pemesanan memiliki

Tabel 3. Hasil Model EOQ

\begin{tabular}{clccc}
\hline Metode EOQ & \multicolumn{1}{c}{ Komponen } & Nilai & Biaya (\$) & Total Biaya (\$) \\
\hline \multirow{2}{*}{ Gandum AH } & Unit Pemesanan & 4955,2 & \multirow{2}{*}{38432,25} & \multirow{2}{*}{2562,15} \\
& Jumlah Pemesanan & 15 & & \\
\cline { 2 - 4 } & Total investasi persediaan & 38754,2 & 845926,68 & \\
\hline \multirow{2}{*}{ Gandum APW } & Unit Pemesanan & 7538 & \multirow{2}{*}{84550,95} & \multirow{2}{*}{2562,15} \\
& Jumlah Pemesanan & 33 & & \\
\cline { 2 - 4 } & Total investasi persediaan & 38074 & 855522,78 & \\
\hline
\end{tabular}


nilai yang sama, tetapi jumlah permintaan satu tahun berbeda.

Biaya yang terhitung dengan melibatkan biaya penyimpanan dengan biaya pemesanan. Biaya penyimpanan adalah \$845.926,68 untuk gandum AH dan \$855.552,78 untuk gandum APW, sedangkan biaya pemesanan adalah \$38.432,25 untuk gandum AH dan \$84.550,95 untuk gandum APW. Berdasarkan kedua jenis biaya ini, maka didapatkan total biaya yang terlibat menggunakan model EOQ adalah $\$ 884.358,93$ untuk gandum $\mathrm{AH}$ dan $\$ 940.073,73$ untuk gandum APW.

\section{Analisis Usulan Persediaan Model POQ}

Model POQ merupakan teknik lot sizing yang bersifat statis, selain model EOQ. Perbedaan hal yang menjadi statis antara model POQ dengan EOQ adalah bila EOQ membuat kuantitas pemesanannya menjadi tetap, maka POQ membuat periode pemesanannya menjadi tetap. Hal ini berarti pada saat periode pemesanan telah ditetapkan, maka pemesanan akan dilakukan sesuai interval yang telah ditetapkan. Berikut adalah hasil penerapan model POQ pada kedua jenis gandum.

Berdasarkan Tabel 4, komponenkomponen yang dimasukkan sedikit berbeda dengan yang dimiliki tabel perhitungan EOQ. Perbedaan pada komponen kedua, yaitu rencana periode pemesanan. Sesuai dengan sifat dari POQ, yaitu memberikan hasil periode pemesanan yang tetap, maka komponen rencana periode pemesanan dimasukkan sebagai ganti kuantitas pemesanan yang sudah bersifat tidak tetap pada model POQ. Berdasarkan tabel hasil perhitungan POQ, didapati frekuensi pemesanan untuk gandum AH adalah 18 kali, sedangkan untuk gandum APW adalah 25 kali. Rencana periode untuk kedua jenis gandum adalah 2 kali dengan jumlah investasi persediaan per bulan selama satu tahun pada saat pembelian terjadi, 40.453, $726 \mathrm{mt}$ untuk gandum $\mathrm{AH}$ dan 137.829,86 mt untuk gandum APW.

Walaupun jumlah minggu aktif dan periode pemesanan sama pada kedua jenis gandum, tetapi frekuensi pemesanan berbeda. Frekuensi pemesanan gandum APW lebih banyak dibandingkan dengan gandum $\mathrm{AH}$. Faktor yang dapat dianalisis sebagai alasan terjadinya fenomena ini adalah persediaan awal yang tersedia sebelum dilakukannya pembelian akibat persediaan tidak mencukupi. Terlihat pada kondisi persediaan awal kedua jenis gandum, gandum $\mathrm{AH}$ memiliki jumlah persediaan yang lebih banyak dibandingkan dengan jumlah persediaan gandum jenis APW, bernilai $30.650 \mathrm{mt}$ untuk gandum AH dan 2.500 mt untuk gandum APW. Faktor lain yang juga mempengaruhi di luar dari studi kasus yang ada adalah besarnya permintaan pada bulan awal. Apabila permintaan pada bulan awal dua jenis barang berbeda, frekuensi pemesanan berdasarkan model POQ akan berbeda walaupun jumlah persediaan awal kedua barang tersebut sama. Frekuensi pemesanan barang yang memiliki jumlah permintaan pada bulan awal yang lebih besar tentu akan lebih besar karena persediaan awal lebih cepat habis.

Periode pemesanan kedua jenis gandum pada tabel bernilai sama. Sebenarnya, nilai periode pemesanan yang terhitung berdasarkan rumus POQ untuk kedua jenis gandum berbeda. Keduanya merupakan nilai desimal antara nilai satu dan dua. Karena nilai desimal tidak memungkinkan untuk dimasukkan kedalam sistem MRP, maka pembulatan keatas dilakukan pada kedua nilai periode pemesanan dan didapati sebesar dua minggu sekali untuk kedua jenis gandum.

Berdasarkan penerapan model POQ,

Tabel 4. Hasil Perhitungan Model POQ

\begin{tabular}{clccc}
\hline Metode POQ & \multicolumn{1}{c}{ Komponen } & Nilai & Biaya (\$) & Total Biaya (\$) \\
\hline \multirow{3}{*}{ Gandum AH } & Unit Pemesanan & 18 & \multirow{2}{*}{46118,70} & \multirow{2}{*}{929142,63} \\
& Jumlah Pemesanan & 2 & & \\
\cline { 2 - 4 } & Total investasi persediaan & 40453,73 & 883023,93 & \\
\hline \multirow{3}{*}{ Gandum APW } & Unit Pemesanan & 25 & \multirow{2}{*}{58929,45} & \multirow{2}{*}{3155966,40} \\
\cline { 2 - 4 } & Jumlah Pemesanan & 2 & & \\
\cline { 2 - 4 } & Total investasi persediaan & 137829,86 & 3097036,95 & \\
\hline
\end{tabular}


biaya pemesanan adalah \$46.118,7 untuk gandum $\mathrm{AH}$ dan \$58.929,45 untuk gandum APW. Biaya penyimpanan adalah \$883.023,83 untuk gandum AH dan \$3.097.036,95 untuk gandum APW. Jumlah dari biaya pemesanan dan biaya penyimpanan merupakan biaya total, yaitu \$929.142,63 untuk gandum AH dan \$3.155.966,4 untuk gandum APW.

\section{Analisis Usulan Persediaan Heuristik SM}

Heuristik Silver Meal merupakan salah satu teknik lot sizing yang bersifat dinamik. Komponen yang bersifat dinamis yang didalam hasil penerapan heuristik SM adalah jumlah pemesanan sekali pesan. Berdasarkan teori mengenai SM pada landasan teori, cara penentuan kuantitas pemesanan sekali pesan dengan menggunakan heuristik SM adalah dengan mencari biaya rata-rata terkecil. Contoh perhitungan dan tabel terperinci. untuk penerapan heuristik SM terdapat di lampiran. Berikut adalah hasil perhitungan yang didapatkan berdasarkan heuristik SM.

Komponen-komponen di dalam tabel hasil perhitungan heuristik SM hanya terdiri dari dua komponen, yaitu jumlah pemesanan dan total investasi persediaan. Kuantitas pemesanan atau pun periode pemesanan tidak dimasukkan menjadi komponen tabel tersebut karena tidak satu pun dari kedua komponen ini yang bersifat tetap berdasarkan perhitungan heuristik SM. Komponen pertama, jumlah pemesanan, bernilai 15 kali untuk gandum $\mathrm{AH}$ dan 29 kali untuk gandum APW. Komponen kedua, total investasi persediaan, bernilai 37.154,618 mt untuk gandum $\mathrm{AH}$ dan 57.194,53 mt untuk gandum APW.
Biaya penyimpanan berdasarkan heuristik SM adalah \$811.011 untuk gandum $\mathrm{AH}$ dan \$1.285.161,09 untuk gandum APW, sedangkan biaya pemesanannya adalah \$38.432,25 untuk gandum AH dan \$74.302,35 untuk gandum APW. Total biaya yang dikonsumsi untuk persediaan adalah $\$ 849443,25$ untuk gandum AH dan \$1.359.463,44 untuk gandum APW.

\section{Analisis Usulan Persediaan Heuristik PPB}

Pendekatan heuristik PPB merupakan teknik lot sizing terakhir yang digunakan di dalam penelitian ini yang bersifat dinamis juga. Di dalam penerapannya, PPB memiliki perbedaan yang terlihat jelas dengan SM. Cara kerja PPB adalah melihat nilai yang paling mendekati antara biaya penyimpanan kumulatif dengan biaya pemesanan sekali pesan. Hal ini mengimplikasikan bahwa nilai biaya penyimpanan kumulatif dapat lebih besar atau lebih kecil dibandingkan dengan biaya pemesanan sekali pesan, bergantung pada nilai mana yang lebih mendekati biaya pemesanan sekali pesan. Sedangkan, SM mencari biaya rata-rata terkecil sehingga tidak mungkin mendapatkan jumlah lot untuk periode tertentu sehingga biaya penyimpanan kumulatif melebihi biaya pemesanan sekali pesan.

Berdasarkan tabel hasil perhitungan heuristik PPB, terlihat komponen-komponen di dalam tabel adalah komponen yang sama dengan tabel heuristik SM. Hal ini dikarenakan oleh jenis lot sizing kedua heuristik adalah sama dalam hal statis-dinamis. Jumlah pemesanan gandum AH selalu lebih sedikit dibandingkan dengan APW, termasuk pada perhitungan heuristik PPB, nilai frekuensi pemesanan

Tabel 5. Hasil Perhitungan SM

\begin{tabular}{|c|c|c|c|c|}
\hline Metode POQ & Komponen & Nilai & Biaya (\$) & Total Biaya (\$) \\
\hline \multirow{2}{*}{ Gandum AH } & Unit Pemesanan & 15 & 38432,25 & \multirow{2}{*}{849443,25} \\
\hline & Total investasi persediaan & 37154,62 & 811011,00 & \\
\hline \multirow{2}{*}{ Gandum APW } & Unit Pemesanan & 29 & 74302,35 & \multirow{2}{*}{1359463,439} \\
\hline & Total investasi persediaan & 57194,53 & 1285161,089 & \\
\hline
\end{tabular}

Tabel 6. Hasil Perhitungan PPB

\begin{tabular}{cllcc}
\hline Metode POQ & \multicolumn{1}{c}{ Komponen } & Nilai & Biaya (\$) & \multirow{2}{*}{ Total Biaya (\$) } \\
\hline \multirow{2}{*}{ Gandum AH } & Unit Pemesanan & 13 & 33307,59 & \multirow{2}{*}{1009852,64} \\
\cline { 2 - 4 } & Total investasi persediaan & 44738,17 & 976344,68 & \\
\cline { 1 - 4 } Gandum APW & Unit Pemesanan & 34 & 21451,8 & \multirow{2}{*}{1294193,55} \\
\cline { 2 - 4 } & Total investasi persediaan & 54895,90 & 1232701,95 & \\
\hline
\end{tabular}


gandum $\mathrm{AH}$ adalah 13 kali dalam satu tahun, sedangkan gandum APW adalah 24 kali. Investasi persediaan pada gandum $\mathrm{AH}$ adalah sebesar 44.738,17 mt, sedangkan pada gandum APW adalah sebesar 54.859,9 mt.

Biaya penyimpanan berdasarkan heuristik PPB adalah \$976.344,68 untuk gandum AH dan \$1.232.701,95 untuk gandum APW, sedangkan biaya pemesanannya adalah \$33.307,95 untuk gandum AH dan \$61.491,6 untuk gandum APW. Total biaya yang dikonsumsi untuk persediaan adalah \$1.009.852,637 untuk gandum $\mathrm{AH}$ dan \$1.294.193,55 untuk gandum APW.

\section{Analisis Perbandingan Lot Sizing}

Semua teknik penentuan ukuran lot menghasilkan ukuran pemesanan yang berbedabeda. Hal ini mengakibatkan besarnya biaya yang terlibat berdasarkan penerapan teknik lot sizing juga berbeda-beda. Oleh sebab itu, analisis perbandingan perlu dilakukan untuk menentukan jenis teknik lot sizing yang tepat yang sebaiknya diterapkan untuk pengendalian persediaan kedua jenis gandum bila diterapkan dalam sistem MRP. Berikut adalah tabel yang menyajikan perbandingan biaya setiap teknik lot sizing.

Berdasarkan Tabel 7 perbandingan biaya persediaan gandum $\mathrm{AH}$, teknik lot sizing yang menghasilkan biaya terkecil adalah penggunaan heuristik SM, yaitu sebesar \$849.443,25. Biaya terkecil kedua adalah penggunaan model EOQ, yaitu sebesar $\$ 884.358,93$. Selisih kedua biaya ini adalah $\$ 34.915,68$. Selisih biaya yang terjadi antara kedua penerapan model ini berasal dari biaya penyimpanan selama satu tahun dimana jenis biaya penyimpanan yang digunakan adalah biaya penyimpanan variabel.

Keputusan akan memihak pada pendekatan teknik lot sizing SM bila didasarkan hanya oleh minimasi biaya. Namun, didalam kenyataan, hal ini terkadang tidak terwujud karena para perencana persediaan juga mempertimbangkan hal-hal lain seperti yang telah dijelaskan pada landasan teori. Salah satu faktor yang dapat dipertimbangkan bila membandingkan model EOQ dan heuristik SM adalah kuantitas pemesanannya. Bila perencana hendak melakukan pembelian bahan baku dengan kuantitas yang tetap, model EOQ dapat memberikan biaya yang minimal.

Usulan Iswara tidak memberikan biaya yang minimum. Hal ini karena komponen biaya yang dimasukkan ke dalam perhitungan tidak tepat. Komponen biaya yang dimasukkan menjadi biaya pemesanan bukan biaya pemesanan yang bersifat tetap. Kemudian, biaya penyimpanan tidak memperhitungkan biaya kesempatan yang hilang karena investasi persediaan. Hal ini mengakibatkan titik pemesanan menjadi tidak optimal dan perlu mengalami revisi.

Berdasarkan Tabel 7 perbandingan biaya persediaan gandum $\mathrm{AH}$, teknik lot sizing yang menghasilkan biaya terkecil adalah penggunaan heuristik SM, yaitu sebesar \$849.443,25. Biaya terkecil kedua adalah penggunaan model EOQ, yaitu sebesar \$884.358,93. Selisih kedua biaya ini adalah $\$ 34.915,68$. Selisih biaya yang terjadi antara kedua penerapan model ini berasal dari biaya penyimpanan selama satu tahun dimana jenis biaya penyimpanan yang digunakan adalah biaya penyimpanan variabel.

Keputusan akan memihak pada pendekatan teknik lot sizing SM bila didasarkan hanya oleh minimasi biaya. Namun, didalam kenyataan, hal ini terkadang tidak terwujud karena para perencana persediaan juga mempertimbangkan hal-hal lain seperti yang telah dijelaskan pada landasan teori. Salah satu faktor yang dapat dipertimbangkan bila membandingkan model EOQ dan heuristik SM adalah kuantitas pemesanannya. Bila perencana hendak melakukan pembelian bahan baku dengan kuantitas yang tetap, model EOQ dapat memberikan biaya yang minimal.

Usulan Iswara tidak memberikan biaya yang minimum. Hal ini karena komponen biaya yang dimasukkan ke dalam perhitungan tidak tepat. Komponen biaya yang dimasukkan menjadi biaya pemesanan bukan biaya pemesanan yang bersifat tetap. Kemudian, biaya penyimpanan tidak memperhitungkan biaya kesempatan yang hilang karena investasi persediaan. Hal ini mengakibatkan titik pemesanan menjadi tidak optimal dan perlu mengalami revisi. 
Tabel 7. Perbandingan Usulan Persediaan Gandum AH

\begin{tabular}{llll}
\hline \multirow{2}{*}{ Teknik Lot Sizing } & \multicolumn{3}{c}{ Biaya Gandum AH } \\
\cline { 2 - 4 } & \multicolumn{1}{c}{ Biaya Pemesana } & \multicolumn{1}{c}{ Biaya Penyimpanan } & Total Biaya \\
\hline Usulan Iswara & 2562,15 & 1779342,16 & 1781904,31 \\
Metode EOQ Revisi & 38432,25 & 845926,68 & 884358,93 \\
Metode POQ & 46118,7 & 883023,93 & 929142,63 \\
Heuristik SM & 38432,25 & 811011 & 849443,25 \\
Heuristik PPB & 33307,95 & 976544,69 & 1009852,64 \\
\hline
\end{tabular}

Tabel 8. Perbandingan Usulan Persediaan Gandum APW

\begin{tabular}{lrrr}
\hline \multirow{2}{*}{ Teknik Lot Sizing } & \multicolumn{3}{c}{ Biaya Gandum APW } \\
\cline { 2 - 4 } & Biaya Pemesana & Biaya Penyimpanan & \multicolumn{1}{c}{ Total Biaya } \\
\hline Usulan Iswara & 2562,15 & 3448425,96 & 3450988,11 \\
Metode EOQ Revisi & 84550,95 & 855522,78 & 940073,73 \\
Metode POQ & 58929,45 & 3097036,95 & 3155966,40 \\
Heuristik SM & 74302,35 & 1285161,09 & 135966,44 \\
Heuristik PPB & 61491,60 & 1232701,95 & 12941193,55 \\
\hline
\end{tabular}

Tabel 8 adalah tabel perbandingan biaya penyimpanan untuk jenis gandum kedua, yaitu gandum APW. Berdasarkan tabel tersebut, biaya persediaan gandum APW terkecil terdapat pada hasil teknik lot sizing dengan menerapkan model EOQ, yaitu sebesar \$940.073,73. Model EOQ disini bukanlah yang model yang diusulkan oleh Iswara (2014). Sebaliknya, biaya hasil pengendalian persediaan yang diusulkan oleh Iswara merupakan biaya yang terbesar diantara pengendalian menggunakan teknik lot sizing yang diusulkan di dalam penelitian ini.

Usulan pengendalian persediaan gandum APW terarah pada model EOQ. Model ini memberikan dua keuntungan dalam kasus jenis gandum ini. Pertama, pengendalian dengan model EOQ akan menghasilkan biaya minimum diantara teknik lot sizing yang dipakai dalam penelitian ini. Kedua, stabilitas pemesanan dalam bentuk kuantitas pemesanan bersifat statis. Sehingga kuantitas pemesanan sekali pesan tidaklah berbeda-beda. Hal ini memberikan peluang yang lebih besar kepada teknik lot sizing EOQ untuk terpilih menjadi pengendalian gandum APW berdasarkan data tahun 2013.

Pengendalian persediaan kedua jenis gandum menggunakan jenis lot sizing yang berbeda. Hal ini membuktikan penggunaan setiap lot sizing pada kasus yang berbeda tidak akan selalu memberikan hasil yang sama sehingga perlu mempertimbangkan beberapa teknik lot sizing untuk melihat yang mana yang dapat dijadikan teknik yang tepat. Selain itu, pengendalian persediaan dapat berubah seiring dengan perubahan komponen-komponen yang dimasukkan dalam perhitungan, seperti rencana jumlah pemakaian, biaya penyimpanan yang tidak selalu tetap, biaya pemesanan yang tidak tetap, dan biaya pembelian gandum per mt. Pendekatan yang umumnya dilakukan, termasuk di dalam penelitian ini adalah mencari nilai rata-rata dari setiap komponen biaya untuk dapat dijadikan nilai yang pasti di dalam perhitungan menggunakan teknik lot sizing.

Tabel 9. Hasil Lot Sizing Terbaik Untuk Dua Jenis Gandum

\begin{tabular}{lllll}
\hline \multirow{2}{*}{ Bulan } & \multicolumn{2}{l}{ Gandum AH } & \multicolumn{2}{c}{ Gandum APW } \\
\cline { 2 - 5 } & Frekwensi & Jumlah & Frekuensi & Jumlah \\
\hline Januari & 0 & 0,00 & 1 & 7538,00 \\
Februari & 0 & 0,00 & 3 & 22614,00 \\
Maret & 0 & 0,00 & 3 & 22614,00 \\
April & 1 & 4039,96 & 3 & 22614,00 \\
Mei & 2 & 10710 & 2 & 15076,00 \\
Juni & 2 & 13435,18 & 2 & 15076,00 \\
Juli & 2 & 8274,81 & 3 & 22614,00 \\
Agustus & 2 & 10880,04 & 3 & 22614,00 \\
September & 1 & 4160,00 & 3 & 22614,00 \\
Oktober & 1 & 3720,00 & 4 & 30152,00 \\
November & 2 & 8280,00 & 3 & 22614,00 \\
Desember & 2 & 10500,00 & 3 & 22614,00 \\
\hline
\end{tabular}

\section{KESIMPULAN}

Berdasarkan hasil penelitian terhadap kebijakan pengendalian persediaan PT Eastern Pearl Flour Makassar yang didasarkan pada studi literatur dengan kasus yang berasal dari skripsi Universitas Hassanudin dengan judul Analisis Pengendalian Persediaan Bahan Baku 
pada PT Eastern Pearl Flour Makassar karya Alfiana Adila Iswara, kesimpulan yang didapatkan adalah sebagai berikut: pengendalian persediaan yang tepat dengan kriteria biaya berdasarkan teknik lot sizing pada jenis gandum $\mathrm{AH}$ adalah heuristik Silver Meal, sedangkan untuk jenis gandum APW adalah model EOQ. Berdasarkan teknik lot sizing yang diterapkan, maka didapatkan frekuensi pembelian dan kuantitas pembelian masingmasing gandum sebagai berikut. Berdasarkan perhitungan biaya persediaan penerapan teknik lot sizing yang terpilih, maka biaya optimal yang terhitung dalam penelitian didapatkan sebesar \$ 849.443,25 untuk gandum AH dan \$ 940.073,73 untuk gandum APW. Biaya persediaan yang terjadi berdasarkan kebijakan perusahaan terhadap kedua jenis gandum pada tahun 2013 adalah \$ 2.579.282,184 untuk gandum AH dan \$ 4.528.924,65 untuk gandum APW. Dengan demikian, peningkatan efisiensi biaya persediaan adalah sebesar $67 \%$ untuk gandum AH dan 79,25 \% untuk gandum APW.

\section{DAFTAR PUSTAKA}

[1]. Iswara, Alfiana Adila. 2014. Analisis Pengendalian Persediaan Bahan Baku pada PT. Eastern Pearl Flour Mills Makassar. Skripsi. Program Studi Manajemen, Fakultas Ekonomi dan Bisnis. Universitas Hasanuddin.

[2]. Stevenson, William. J. 1996. Production / Operations Management. United States of America : Irwin.

[3]. Nahmias, Steven. 2005. Production and Operations Analysis. Singapore : McGraw-Hill.

[4]. Wignjosoebroto, Sritomo. 2003. Pengantar Teknik dan Manajemen Industri edisi pertama. Surabaya : Guna Widya.

[5]. Harris, Ford W. Operations Cost (Factory Management Series), Chicago: Shaw (1915)

[6]. Wagner, H. M. and T. M. Whitin (1958), "Dynamic Version of the Economic Lot Size Model,” Management Science, 9, 1, 89-96.

[7]. Silver, E. A., Pyke, D. F., \& Peterson, R. (1998). Inventory Management and
Production Planning and Scheduling. (3th ed.). New York: John Wiley \& Sons.

[8]. Slack, Nigel et al. 2007. Operations Management 5th edition. Madrid : Prentice Hall.

[9]. Baciarello, Luca et al. 2013.”Lot Sizing Heuristics Performance". International Journal of Engineering Business Management vol. 5, 1-10.

[10]. Forgaty, Donald W. Et al. 2001. Production and Inventory Management. United States of America : South Western Publishing.

[11]. Groover, Mikell P. 2001. Automation, Production Systems, and Computer Integrated Manufacturing 3rd Edition. United States of America : Pearson

[12]. Heizer, Jay dan Barry Render. 2008. Operations Management ninth edition. United States of America : Pearson.

[13]. Pujawan, I Nyoman. 2001. "Evaluasi Kinerja Metode - Metode Lot Sizing dengan Kriteria Majemuk”.Majalah IPTEK vol. 12, 123 - 134.

[14]. Rahmayanti, Dina dan Ahmad Fauzan. 2013. "Optimalisasi Sistem Persediaan Bahan Baku Karet Mentah (Lateks) Dengan Metode Lot Sizing (Studi Kasus : PT Abaisiat Jaya). Jurnal Optimasi Sistem Industri ISSN 2088-4842, 317-325.

[15]. Reid, R. Dan dan Nada R. Sanders. 2011. Operations Management 4th edition. United States of America : John Wiley \& Sons.

[16]. Sanchez, S.N. dan kawan-kawan. 2001. "A Study of Total Inventory Cost as A Function of the Reorder interval of Some Lot Sizing Techniques Used in Material Requirement Planning Systems”. Computer \& Industrial Engineering Journal vol. 40, 101-116.

[17]. Taryana, Nanang. 2008. Analisis Pengendalian Persediaan Bahan Baku pada Produk Sepatu dengan Pendekatan Teknik Lot Sizing dalam Mendukung sistem MRP ( Studi Kasus di PT. Sepatu Mas Idaman, Bogor ). Skripsi. Program Studi Teknologi Pertanian, Fakultas 
Pengendalian Persediaan Bahan Baku Dengan Pendekatan Teknik Lot Sizing (Studi Kasus: PT. Eastern Pearl Flour Makasar) Panca Jodiawan dan Hendy Tannady

Teknologi Pertanian. Institut Pertanian Bogor.

[18]. Ullah, Hafiz dan Sultana Parveen. 2010. "A Literature Review on Inventory Lot Sizing Problems". Global Journal of Reseaches in Engineering vol. 10, 21-37. 